\title{
INCREASED FREQUENCY OF THE UNCOMMON ALLELE OF A TUMOUR NECROSIS FACTOR ALPHA GENE POLYMORPHISM IN RHEUMATOID ARTHRITIS AND SYSTEMIC LUPUS ERYTHEMATOSUS
}

\author{
VICTOR A. DANIS $\$$, MICHELLE MILLINGTON\$, VALENTINE HYLAND\$, RON LAWFORD ${ }^{\dagger}$, \\ QIRONG HUANG ${ }^{\dagger}$, DAVID GRENNAN ${ }^{\dagger}$

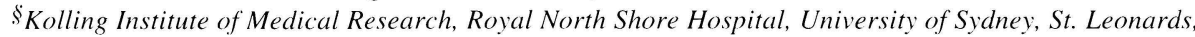 \\ NSW 2065, Australia. \\ tDepartment of Rheumatology, University of Sydney.
}

\section{SUMMARY}

The frequency of the uncommon allele (TNF2) of a polymorphism in the promoter region of the tumour necrosis factor alpha (TNF $\alpha$ ) gene in patients with rheumatoid arthritis (RA) and systemic lupus erythematosus (SLE) was found to be 3 times that of the normal anglo-saxon population. In SLE patients, this allele was strongly associated with HLA-DR3 expression and was also more frequent in patients who did not have malar rash. Functional studies of normal monocyte cytokine production in vitro showed that this genotype was associated with increased IL- $1 \alpha$ protein production but there were no differences in the production of TNF $\alpha$ protein.

KEY WORDS Tumour necrosis factor Polymorphism SLE RA

\section{INTRODUCTION}

Rheumatoid arthritis (RA) and Systemic lupus erythematosus (SLE) are autoimmune diseases of unknown aetiology but with a genetic predisposition which is only partly accounted for by genes within the HLA region (Grennan and Dyer, 1988; Grennan et al., 1994). Cytokine genes such as TNF $\alpha$ may be candidate genes responsible for some of the undefined genetic predisposition in autoimmune diseases. TNF $\alpha$ has been shown to contribute to genetic predisposition to murine lupus (Jacob, 1992) and recent treatment of RA patients with anti-TNF $\alpha$ antibodies has been shown promising results (Elliott et al., 1993). Restriction fragment length polymorphism analysis of the TNF $\alpha$ locus using the endonuclease $N c o$ I has revealed an increase in the frequency of the $5.5 \mathrm{~kb}$ fragment in SLE but not in RA (Tomita et al.,1993; Fugger et al., 1989). Recently, a polymorphism in the promoter sequence of the TNF $\alpha$ gene has been described (Wilson et al., 1992). The frequency of the uncommon allele (TNF2) in the latter report was low (16\%) and concur with our results that show a frequency of $12 \%$ in the normal anglo-saxon population. Here we report that the frequency of the TNF2 allele is significantly increased in RA $(31 \%)$

Correspondence to: Dr V.A. Danis, Kolling Institute of Medical Research, Royal North Shore Hospital. St. Leonards, NSW 2065, Australia. Tel: (61 2) 4387188, Fax: (61 2) 4392798. 
and SLE (30\%) patient groups, and that this genotype may be associated with increased IL- $1 \alpha$ production by monocytes.

\section{MATERIALS AND METHODS}

\section{Patients}

Thirty four patients with classic or definite RA by the criteria of the American Rheumatism Association (ARA) (Ropes et al., 1958) and 40 unrelated patients with SLE by the criteria of the ARA (Tan et al., 1982) were studied. Patients with SLE were subgrouped according to the following parameters: malar rash, photosensitivity, renal proteinuria, antinuclear antibody (SSA), and HLA-DR3 type. In addition, 57 healthy anglo-saxon Caucasian controls were studied.

\section{PCR analysis of IL-1 ra gene polymorphism}

Genomic DNA was extracted from $20 \mathrm{ml}$ of EDTA blood by proteinase K digestion, phenol-chloroform extraction and ethanol precipitation using an established protocol (Wyman, R. and White, 1980). 200ng of DNA in $50 \mu \mathrm{l}$ reaction buffer was subjected to PCR amplification for the $107 \mathrm{bp}$ sequence containing the polymorphic site of the TNF $\alpha$ gene in a GeneAmp PCR System 9600 (Perkin Elmer) using the primers as described (Wilson et al., 1992). The polymorphism is a base change from $\mathrm{G}$ to $\mathrm{A}$ at position -308 and the forward primer created an NcoI recognition site which could be used to detect the polymorphism. Primers were synthesised using a 391 DNA Synthesiser (PCR-Mate, Applied Biosystems). The reaction buffer consisted of $10 \mathrm{mM}$ Tris $\mathrm{pH} 8.8$ with $75 \mathrm{mM}$ $\mathrm{KCl}$ and $1.5 \mathrm{mM} \mathrm{MgCl}_{2}$.

DNA was subjected to a preliminary cycle of $94^{\circ}$ for 3 minutes, $60^{\circ} \mathrm{C}$ for one minute and $72^{\circ} \mathrm{C}$ for one minute. This was followed by 35 cycles of the following: $94^{\circ} \mathrm{C}$ for 30 seconds, for $60^{\circ} \mathrm{C}$ for 30 seconds and $72^{\circ} \mathrm{C}$ for 60 seconds. The final cycle was $94^{\circ} \mathrm{C}$ for 30 seconds, for $60^{\circ} \mathrm{C} 30$ seconds and $72^{\circ} \mathrm{C}$ for 5 minutes. PCR products were digested with $\mathrm{NcoI}$ and separated by electrophoresis on $10 \%$ polyacrylamide gels and visualised by ethidium bromide staining. Allele 1 was recognized by a band $87 \mathrm{bp}$ in size representing the larger fragment of a cut at position 20 of the 107bp PCR fragment. Allele 2 was recognised as an uncut nucleotide of $107 \mathrm{bp}$. Heterozygotes were recognised by the appearance of 2 bands ( $87 \mathrm{bp}$ and 107bp) clearly distinguishable on the gels. A molecular ladder ranging from $67 \mathrm{bp}$ to $500 \mathrm{bp}$ (pUCHpaII, Bresatec) was used to determine the size of the PCR fragments.

\section{Monocyte isolation and culture}

$50-60 \mathrm{ml}$ of venous blood was collected from 35 healthy volunteers 116 male and 20 female), using $0.38 \%$ sodium citrate as anti-coagulant. Monocyte isolation and enrichment were achieved by density gradient and counterflow centrifugation steps as previously described (Danis et al., 1990; Danis and Millington. 1994). Recovery of monocytes was greater than $85 \%$ and monocyte enrichment was greater than $80 \%$ by the criterion of latex ingestion. Purified monocytes were cultured in liquid suspension in $70 \times 11 \mathrm{~mm}$ Minisorp tubes (Nunc) which had been sterilised by ethylene oxide,. The culture medium was X-Vivo 15 (BioWittaker) containing recombinant human granulocyte-macrophage colony stimulating factor (rGM-CSF, $10 \mathrm{ng} / \mathrm{ml}$ ) and recombinant human interferon gamma (rIFN $\gamma, 5 \mathrm{ng} / \mathrm{ml})$ as stimulant. 
Monocytes were cultured at $10^{6} / \mathrm{ml}$ in a total volume of $0.4 \mathrm{ml}$ in tubes fitted with a loose cap in $5 \% \mathrm{CO}_{2}$ in air in a humidified incubator. After 20 hours the tubes were centrifuged at $200 \mathrm{~g}$ for 10 minutes and the supernatants harvested. The cells were resuspended in $0.4 \mathrm{ml}$ of fresh culture medium and disrupted by sonication for 10 seconds at 50W using a Labsonic 2000 ultrasonic homogeniser (B. Braun Instruments, Sydney, Australia) with a $4 \mathrm{~mm}$ titanium needle probe. This was used to estimate the cellassociated IL-1 activity. Levels of cell-associated IL- 6 and TNF $\alpha$ were consistently low $(<0.3 \mathrm{ng} / \mathrm{ml})$ and were not routinely measured. Samples were stored at $-20^{\circ} \mathrm{C}$ for up to 4 weeks prior to assay.

\section{Cytokines and cytokine ELISAs}

Sandwich ELISAs specific for IL-1 $\alpha$, IL-1 $\beta$, IL-1 ra, IL-6 and TNF $\alpha$ were developed and used as previously described (Danis et al., 1991; 1994). Recombinant human IFN $\gamma$ and recombinant human $\mathrm{TNF} \alpha$ were provided by Boehringer Ingelheim (Austria), recombinant human GM-CSF by the Schering Corporation (Sydney, Australia), recombinant human IL-1ra by the Upjohn Company (Kalamazoo, USA), and recombinant human IL-6 by Dr. Gordon Wong (Genetics Institute, USA). Recombinant human IL- $1 \alpha$ and IL-1 $\beta$ were purchased from Boehringer-Mannheim (Sydney, Australia).

\section{Statistical Analysis}

The results are presented as genotypes and allele frequencies. The Chi-square test for statistical significance was performed on allelic frequencies. The Mann-Whitney U Test was used to compare cytokine protein production by monocytes from genotypically distinct normal healthy individuals.

\section{RESULTS AND DISCUSSION}

The TNF $\alpha$ genotype and allele frequencies in RA and SLE patients and controls are summarised in Table 1 . The frequency of allele 2 in RA patients $(31 \%)$ and in SLE patients $(30 \%)$ was significantly higher than in controls $(12 \%)$. The frequency of the expression of TNF2 in normal populations has previously been reported to be between $7 \%$ (Verjans et al., 1994) and 22\% (Mansfield et al., 1994). Increased frequency of TNF2 in SLE patients has recently been reported by Wilson et al. (1994). When we looked at disease subgroups in our SLE patients we found significantly higher expression of TNF2 in patients with HLA-DR3 haplotype, patients without malar rash, patients positive for the antinuclear antibody SSA and patients with renal proteinuria (Table 2). On the other hand, there was no difference in the frequency of expression of TNF2 in SLE patients with photosensitivity compared with those with no photosensitivity.

The TNF locus is in close proximity to the HLA locus and it is difficult to determine whether the polymorphism at the TNF locus is having a direct effect or is in linkage disequilibrium with a polymorphism in the HLA region, especially in HLA-DR. Genetic susceptibility to RA is partly accounted for by HLA-DR4 (Grennan and Dyer, 1988) and genetic susceptibility to SLE is partly accounted for by HLA-DR3 (Grennan et al., 1994). Previous work has shown TNF2 is associated with HLA-A1, B8 and DR3 alleles (Wilson et al., 1993) and, at least in the context of Diabetes mellitus, it was not possible to show an independent association of TNF2 with disease (Pociot et al., 1993). Our results confirm an association between TNF2 and HLA-DR3 in SLE patients. However, there 
Table 1. TNF $\alpha$ genotypes and allele frequencies in healthy and diseased populations.

\begin{tabular}{lccccccc}
\hline & \multicolumn{3}{c}{ Genotype } & & \multicolumn{2}{c}{ Allele Frequencies (\%) } \\
\cline { 2 - 4 } \cline { 6 - 7 } & 1,1 & 1,2 & 2,2 & & 1 & 2 \\
\hline Healthy controls $(\mathrm{n}=57)$ & 44 & 13 & 0 & & 88 & 12 \\
RA (n=34) & 17 & 13 & 4 & & 69 & $31^{*}$ \\
SLE $(\mathrm{n}=40)$ & 19 & 18 & 3 & & 70 & $30^{*}$ \\
\hline
\end{tabular}

* $\mathrm{p}<0.001$ compared with the normal control population, Chi-square test.

Table 2. TNF $\alpha$ genotypes and allele frequencies in SLE sub-groups.

\begin{tabular}{|c|c|c|c|c|c|}
\hline & \multicolumn{3}{|c|}{ Genotype } & \multicolumn{2}{|c|}{ Allele Frequencies $(\%)$} \\
\hline & 1,1 & 1,2 & 2,2 & 1 & 2 \\
\hline $\begin{array}{l}\text { Healthy controls } \\
(n=57)\end{array}$ & 44 & 13 & 0 & 88 & 12 \\
\hline SLE: & & & & & \\
\hline $\begin{array}{l}\text { Malar Rash } \\
\text { +ve }(n=21)\end{array}$ & 14 & 5 & 2 & 79 & $\begin{array}{r}21 \\
(0.11)\end{array}$ \\
\hline $\begin{array}{l}\text { Malar Rash } \\
\text {-ve }(n=15)\end{array}$ & 4 & 10 & 1 & 60 & $\begin{array}{r}40 \\
(0.0002)\end{array}$ \\
\hline $\begin{array}{l}\text { Photosensitivity } \\
(+ \text { ve }(n=23)\end{array}$ & 12 & 9 & 2 & 72 & $\begin{array}{r}28 \\
(0.01)\end{array}$ \\
\hline $\begin{array}{l}\text { Photosensitivity } \\
\text {-ve }(n=13)\end{array}$ & 6 & 6 & 1 & 69 & $\begin{array}{r}31 \\
(0.01)\end{array}$ \\
\hline $\begin{array}{l}\text { Renal Proteinuria } \\
(+ \text { ve }(n=7)\end{array}$ & 2 & 4 & 1 & 57 & $\begin{array}{r}43 \\
(0.002)\end{array}$ \\
\hline $\begin{array}{l}\text { Renal Proteinuria } \\
\text {-ve }(n=29)\end{array}$ & 16 & 11 & 2 & 74 & $\begin{array}{r}26 \\
(0.015)\end{array}$ \\
\hline $\begin{array}{l}\text { SSA } \\
+ \text { ve }(n=8)\end{array}$ & 2 & 5 & 1 & 56 & $\begin{array}{r}44 \\
(0.001)\end{array}$ \\
\hline $\begin{array}{l}\text { SSA } \\
\text {-ve }(n=28)\end{array}$ & 16 & 10 & 2 & 75 & $\begin{array}{r}25 \\
(0.02)\end{array}$ \\
\hline $\begin{array}{l}\text { HLA DR3 } \\
\text { +ve }(n=10)\end{array}$ & 1 & 8 & 1 & 50 & $\begin{array}{r}50 \\
(0.00001)\end{array}$ \\
\hline $\begin{array}{l}\text { HLA DR3 } \\
\text {-ve }(n=22)\end{array}$ & 15 & 6 & 1 & 82 & $\begin{array}{r}18 \\
(0.26)\end{array}$ \\
\hline
\end{tabular}

Chi-square frequency probability compared with the normal control population is shown in brackets. 
Table 3. Cytokine production by normal monocytes stimulated with GM-CSF+IFN $\gamma$ in relation to TNF $\alpha$ genotype.

\begin{tabular}{|c|c|c|c|}
\hline & TNF1 Genotype & TNF2 Genotype & \\
\hline Cytokine Component & $\begin{array}{l}\text { Median }(\mathrm{ng} / \mathrm{ml}) \\
\quad(\mathrm{n}=29)\end{array}$ & $\begin{array}{l}\text { Median }(\mathrm{ng} / \mathrm{ml}) \\
\quad(\mathrm{n}=6)\end{array}$ & $\mathrm{p}$ value \\
\hline Secreted IL- $1 \alpha$ & 0.95 & 2.88 & 0.01 \\
\hline Cell-Associated IL- $1 \alpha$ & 9.8 & 18.6 & 0.04 \\
\hline Total IL- $1 \alpha$ & 10.5 & 20.9 & 0.05 \\
\hline Secreted IL- $1 \beta$ & 13.9 & 22.5 & 0.17 \\
\hline Cell-Associated IL-1 $\beta$ & 78 & 80.8 & 0.5 \\
\hline Total IL-1 $\beta$ & 93.9 & 103.1 & 0.27 \\
\hline Secreted IL-1 ra & 7.15 & 6.2 & 0.6 \\
\hline Cell-associated IL-1 ra & 2.0 & 1.6 & 0.5 \\
\hline Total IL-1 ra & 9.3 & 9.5 & 0.71 \\
\hline Secreted IL-6 & 33.8 & 10.8 & 0.46 \\
\hline Secreted TNF $\alpha$ & 4.2 & 5.9 & 0.79 \\
\hline
\end{tabular}

Median values from T.NFl individuals (A1A1) are compared with TNF2 individuals (A1A2). Significance levels were obtained using the Mann-Whitney U test. Monocytes were cultured at a million per $\mathrm{ml}$ in serum-free medium for 20 hours as outlined in Materials and Methods.

are also associations between T.NF2 and other disease features in SLE such as malar rash, renal proteinuria and antinuclear antibody expression which are not associated with HLA-DR3 expression (Grennan et al., 1994).

The functional significance of the polymorphism in the promoter region of the TNF $\alpha$ gene is still not known. The regulation of TNF $\alpha$ protein production is primarily post-transcriptional. We have not been able to demonstrate an association between the TNF2 allele and TNF $\alpha$ protein production by normal human monocytes stimulated with GM-CSF and IFN $\gamma$ in vitro. Other workers have failed to demonstrate an association between the TNF2 allele and TNF $\alpha$ production in LPS-stimulated monocyte cultures (Pociot et al. . 1993). We also did not find any association between TNF $\alpha$ genotype and the production of IL-1 $\beta$, IL-1 ra or IL- 6 proteins by monocytes (Table 3). However, there was a significant association between TNF2 and increased IL- $1 \alpha$ production by monocytes in vitro (Figure 1). This may be due to enhanced TNF $\alpha$ production early in culture and more detailed kinetic studies are required to resolve this point.

\section{CONCLUSION}

Expression of the TNF2 allele is increased in autoimmune disease and upregulation of IL- $1 \alpha$ production may partly explain the functional significance of this polymorphism. 


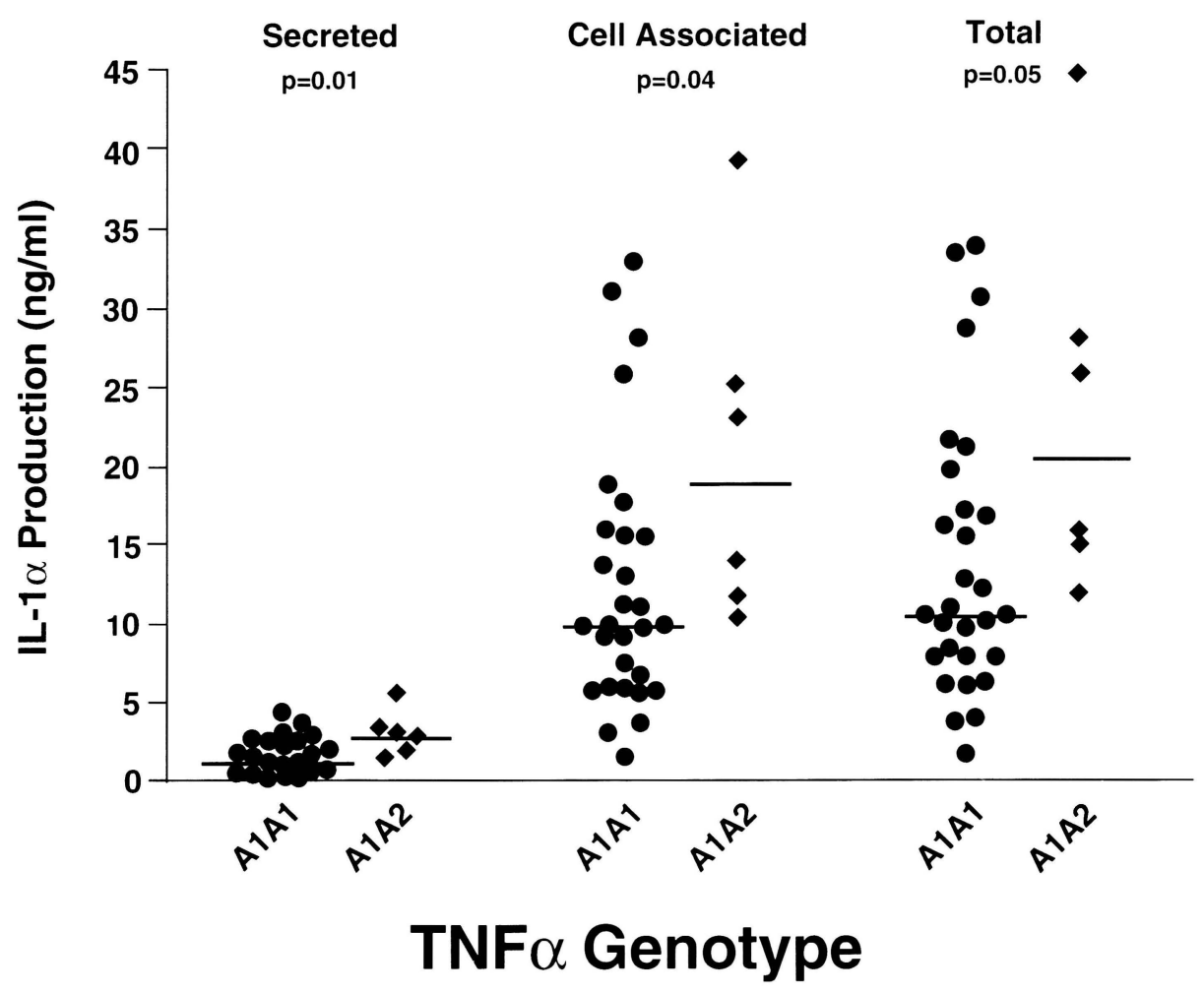

Figure 1. Relationship between the production of IL- $1 \alpha$ protein by human monocytes and TNF $\alpha$ genotype. Purified human monocytes from healthy volunteers were stimulated with GM-CSF and INF $\gamma$ for 20 hours before the supernatants and cell lysates were collected and assayed for cytokine production. Each point represents the mean of two estimations of the IL- $1 \alpha$ protein production from a given individual. Circles represent the A1A1 genotype, and diamonds represent the A1 A2 genotype. Horizontal bars indicate medians. Data are expressed as total IL- $1 \alpha$ production or as the secreted and cell-associated components respectively. The significance levels were determined by the Mann Whitney U test.

\section{ACKNOWLEDGEMENT}

We are grateful to Dr. Les Schrieber, Dr. Nick Manolios and Ms Annette Parfitt for assistance in collecting clinical samples. This work has been supported by grants from the Northern Sydney Area Health Service and the Bone and Joint Research Foundation of the University of Sydney.

\section{REFERENCES}

Danis, V., Millington, M. (1994). Gentle separations suit the cell. Today's Life Sciences, 6, 4044.

Danis, V.A., Millington, M., Grennan, D. (1995). Cytokine production by normal human monocytes: inter-subject variation and relationship to an interleukin-1 receptor antagonist polymorphism. Clin. Exp. Immunol. In press. 
Danis, V.A., Franic, G.M., Rathjen, D.A., Brooks, P.M. (1991). The effects of granulocytemacrophage colony-stimulating factor (GM-CSF), interleukin 2 (IL-2), interferon (IFN)gamma, tumour necrosis factor (TNF)-alpha and IL-6 on the production of immunoreactive IL1 and TNF-alpha by human monocytes. Clin. Exp. Immunol., 85, 143-150.

Danis, V.A., Kulesz, A.J., Nelson, D.S., Brooks, P.M. (1990). Cytokine regulation of human monocyte interleukin-1 (Il-1) production in vitro. Enhancement of IL-1 production by interferon (IFN) gamma, tumour necrosis factor-alpha, IL-2 and IL-1, and inhibition by IFN-alpha. Clin. Exp. Immunol., 80, 435-443.

Elliot, M.J., Maini, R.N., Feldmann, M. Long Fox, A., Charles, P., Katsikis, P., Brennan, F.M., Walker, J., Bijl, H., Ghrayeb, J. et al. (1993). Treatment of rheumatoid arthritis with chimeric monoclonal antibodies to tumour necrosis factor alpha. Arthritis Rheum., 36, 1681-1690.

Fugger, L., Morling, N., Ryder, L.P., Georgsen, J., Jakobsen, B.K., Svejgaard, A., Andersen, V., Oxholm, P., Karup Pedersen, F., Friis, J. et al. (1989). Ncol restriction fragment length polymorphism (RFLP) of the tumor necrosis factor (TNF alpha) region in four autoimmune diseases. Tissue Antigens, 34, 17-22.

Grennan, D.M., Dyer, P.A. (1988). Immunogenetics and rheumatoid arthritis. Immunol. Today, 9, 33-34.

Grennan, D.M., Parfitt, A., Manolios, N., Huang, Q., Hyland, V., Dunckley, H., Doran, T., Gatenby, P., Badcock, C. (1994). Family and twin studies in Systemic Lupus Erythematosus. Submitted for publication.

Jacob, C.O. (1992). Studies on the role of tumor necrosis factor in murine and human autoimmunity. J. Autoimmun., 5 Suppl. A., 133-143.

Mansfield, J.C., Holden, H. Tarlow, J.K., di Giovine, F.S., McDowell, T.L., Wilson, A.G., Holdsworth, C.D., Duff, G.W. (1994). Novel genetic association between ulcerative colitis and the anti-inflammatory cytokine interleukin-1 receptor antagonist. Gastroenterology, 106, 637642.

Pociot, F., Wilson, A.G., Nerup, J., Duff, G.W. (1993). No independent association between a tumor necrosis factor-alpha promoter region polymorphism and insulin-dependent diabetes mellitus. Eur. J. Immunol., 23, 3050-3053.

Ropes, M.W., Bennett, E.A., Cobb, S., Jacox, R., Jessar, R. (1958). Revision of diagnostic criteria for rheumatoid arthritis. Bull. Rheum. Dis., 9, 175-176.

Tan, E.M., Cohen, A.S., Fries, J.F., Masi, A.T., McShane, D.J., Rothfield, N.F., Schaller, J.G., Talal, N., Winchester, R.J. (1982). The 1982 revised criteria for the classification of systemic lupus erythematosus. Arthritis Rheum., 25, 1271-1277.

Tomita, Y., Hashimoto, S., Yamagami, K., Sawada, S., Horie, T. (1993). Restriction fragment length polymorphism (RFLP) analysis in the TNF genes of patients with systemic lupus erythematosus (SLE). Clin. Exp. Rheumatol., 11, 533-536.

Verjans, G.M., Brinkman, B.M., Van Doornik, C.E., Kijlstra, A., Verweij, C.L. (1994). Polymorphism of tumour necrosis factor-alpha (TNF $\alpha)$ at position -308 in relation to ankylosing spondylitis. Clin. Exp. Immunol., 97, 45-47.

Wilson, A.G., de Vries, N., Pociot, F., di Giovine, F.S., van der Putte, L.B., Duff, G.W. (1993). An allelic polymorphism within the human tumor necrosis factor alpha promoter region is strongly associated with HLA-A1, B8 and DR3 alleles. J. Exp. Med., 177, 557-560.

Wilson, A.G., di Giovine, F.S., Blakemore, A.I., Duff, G.W. (1992). Single base polymorphism in the human tumour necrosis factor alpha (TNF alpha) gene detectable by $N c o$ I restriction of PCR product. Hum. Mol. Genet., 1, 353.

Wilson, A.G., Gordon, C., de Vries, N., van de Putte, L.B.A., Emery, P., Duff, G.W. (1994). A genetic association between systemic lupus erythematosus and tumor necrosis factor alpha. Eur. J. Immunol., 24, 191-195.

Wyman, A.R., White, R. (1980). A highly polymorphic locus in human DNA. Proc. Natl. Acad. Sci. USA, 77, 6754-6758. 


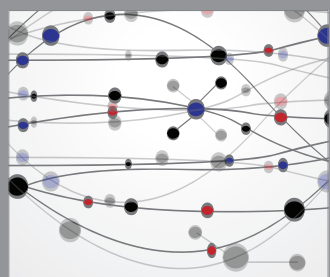

The Scientific World Journal
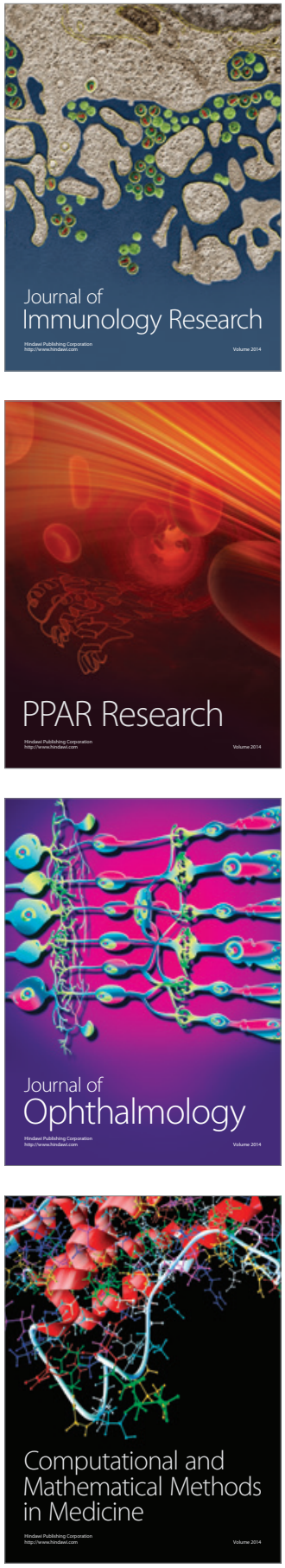

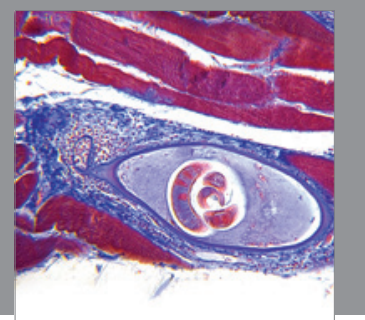

Gastroenterology

Research and Practice
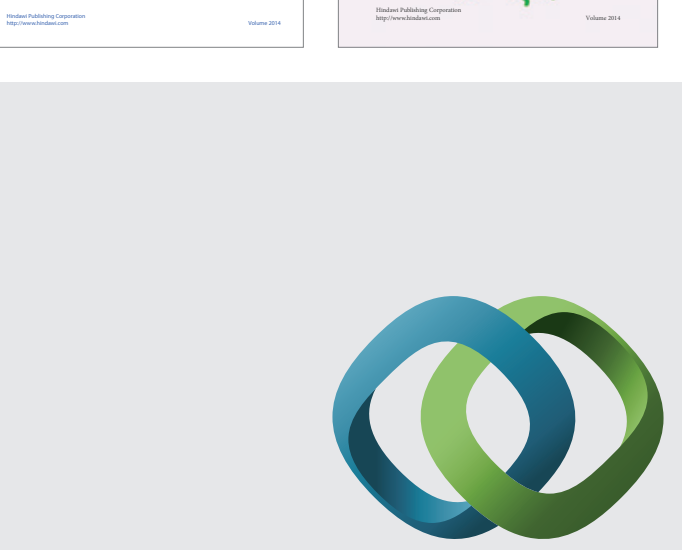

\section{Hindawi}

Submit your manuscripts at

http://www.hindawi.com
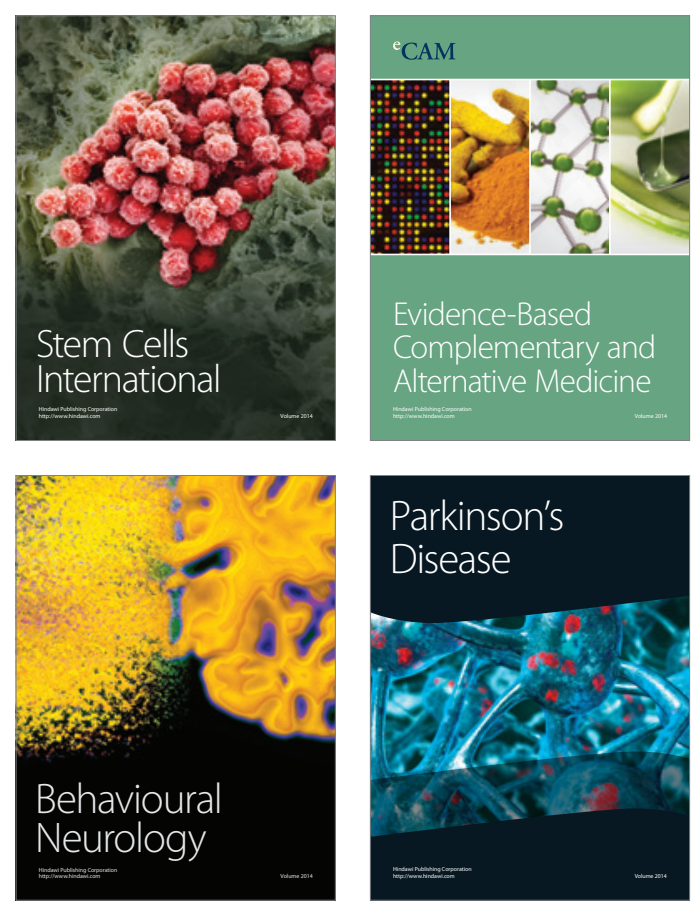

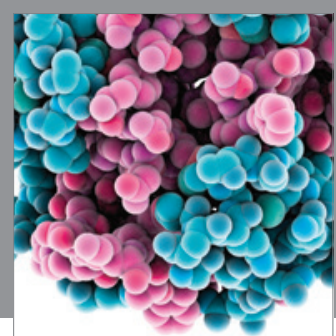

Journal of
Diabetes Research

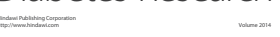

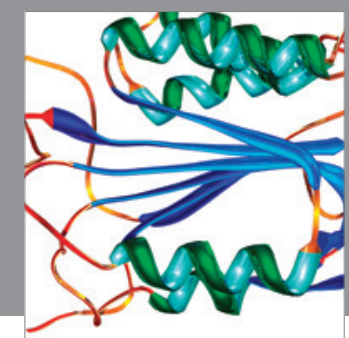

Disease Markers
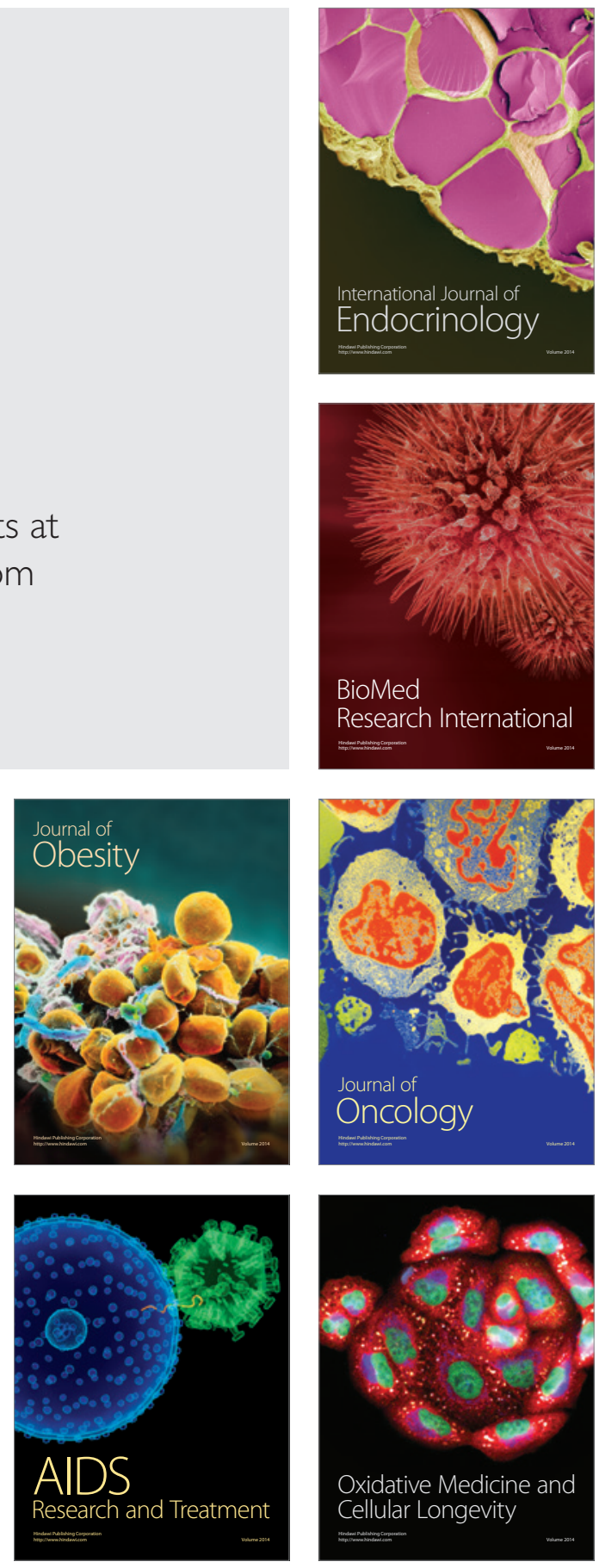